\title{
Comprehensive Comparison between Snoring and Non-Snoring Children
}

\author{
Dong-Hyouk Shin ${ }^{1}$, Seok-Chan Hong ${ }^{1}$, Yong Won Kim ${ }^{1}$, Jeffrey D. Suh², Sochung Chung ${ }^{3}$, \\ Seung-Hoon Lee ${ }^{4}$, Ji Ho Choi ${ }^{4}$, Jeong In $\mathrm{Oh}^{4}$, In-Tae Kim ${ }^{5}$, Jin Kook Kim ${ }^{1}$, and Jae Hoon Cho \\ ${ }^{1}$ Departments of Otorhinolaryngology-Head and Neck Surgery, ${ }^{3}$ Pediatrics, School of Medicine, Konkuk University, Seoul, Korea; \\ ${ }^{2}$ Department of Head and Neck Surgery, UCLA School of Medicine, Los Angeles, CA, USA; \\ ${ }^{4}$ Department of Otorhinolaryngology-Head and Neck Surgery, College of Medicine, Korea University, Ansan; and \\ ${ }^{5}$ Neodin Medical Institute, Seoul, Korea
}

\section{코골이 소아와 비코골이 소아의 다방면 비교}

신동혁 ${ }^{1}$ 홍석찬 ${ }^{1} \cdot$ 김용운 $^{1} \cdot$ Jeffrey D. $\mathrm{Suh}^{2} \cdot$ 정소정 $^{3} \cdot$ 이승훈 ${ }^{4} \cdot$ 최지호 ${ }^{4} \cdot$ 오정인 $^{4} \cdot$ 김인태 $^{5} \cdot$ 김진국 $^{1} \cdot$ 조재훈 $^{1}$

건국대학교 의학전문대학원 이비인후-두경부외과학교실, ${ }^{1}$ 소아과학교실, ${ }^{3} \mathrm{UCLA}$ 의과대학 두경부외과학교실, ${ }^{2}$

고려대학교 의과대학 이비인후-두경부외과학교실, ${ }^{4}$ 네오딘의학연구소 ${ }^{5}$

Received June 26, 2014

Revised August 28, 2014

Accepted August 29, 2014

Address for correspondence

Jae Hoon Cho, MD, PhD

Department of Otorhinolaryngology-

Head and Neck Surgery,

School of Medicine,

Konkuk University,

120-1 Neungdong-ro, Gwangjin-gu,

Seoul 143-729, Korea

Tel +82-2-2030-7667

Fax +82-2-2030-5299

E-mail jaehoon@kuh.ac.kr
Background and Objectives Snoring is very common among children; however, there is a controversy regarding its effects on children. The purpose of this study is to identify risk factors and comorbidities associated with the condition collectively.

Subjects and Method 208 children were invited to participate in this study. Parents were surveyed for each child's snoring status, chronic rhinitis, behavior, and the parents' snoring and smoking status. Measurements were taken of each child's height, weight, waist and neck circumference, and blood pressure. X-rays and physical exams were used to record tonsil and adenoid size. All children also received an intelligence test and comprehensive blood test. Results were then compared between snoring and non-snoring children.

Results Among 208 children, 175 participated in the study voluntarily. Out of the participants, 55 were snorers and 120 were non-snorers. Body mass index, neck and waist circumferences, and prevalence of chronic rhinitis were higher among the snorer. Mothers of snoring children snored more frequently. Inattention and impulsivity scores were also higher among snorers than non-snorers. There were no differences of cognition, tonsil or adenoid size, or blood test results between the two.

Conclusion There were some differences in physical, family-related, and behavior trait between snoring and non-snoring children.

Korean J Otorhinolaryngol-Head Neck Surg 2015;58(3):187-92

Key Words Child $\cdot$ Sleep-disordered breathing $\cdot$ Snoring.

\section{서 론}

코골이는 수면 중 상기도 연조직이 떨려서 발생하는 소리 로, 폐쇄성수면무호흡증후군의 주증상이기도 하며, 그 자체 로 독립된 질환으로 간주된다. ${ }^{1,2}$ 코골이 빈도에 대해서는 연 구들마다 매우 큰 차이를 보이는데, 이는 코골이의 강도나 빈
도에 대해 명확한 정의가 없어, 연구마다 다른 기준을 사용하 였기 때문으로 생각된다. ${ }^{1-5)}$ 과거에는 폐쇄성수면무호흡증후 군이 동반되지 않는 단순 코골이의 경우 별다른 문제가 없다 고 여겨졌으나, 최근에는 고혈압, 심혈관 질환 및 주간 졸림 이 증가된다는 보고들이 발표되고 있다. ${ }^{6-8)}$ 특히 소아들의 경 우 성장 및 학습능력 저하, 주의력 결핍 등과의 관련성이 꾸준 
히 제기되고 있다. ${ }^{1)}$ 하지만, 소아 코골이에 대한 대부분의 연 구는 미국, 유럽 등에서 시행되었고, 국내에서는 상대적으로 적은 수의 연구만이 이루어졌다. 더욱이 신체 및 혈액 검사, 행 동 평가, 출산 및 가족력 등 다방면에 대해 포괄적으로 시행 된 연구는 거의 없었다.

이에 저자들은 코골이 소아와 비코골이 소아에 대한 다방 면 비교를 통해, 한국 코골이 소아의 특징에 대해 파악하고 자 하였다.

\section{대상 및 방법}

서울의 한 공립초등학교의 208명 1학년 학생 전부를 대상 으로 하였다. 연구 참여에 동의한 경우, 부모로부터 서면 동의 서를 받은 후 연구를 시행하였고, 참여를 원하지 않는 경우는 제외하였다. 또한 이전에 편도선 절제술, 아데노이드 절제술, 편도선 및 아데노이드 절제술을 받은 학생들도 연구에서 제 외하였다.

본 연구는 신체검사, 학부모 설문 및 지능검사, 체혈검사로 나누어 하였다.

\section{신체검사}

학생들의 신장, 체중을 측정해 체질량 지수를 계산한 후, 2007년 한국 아동 및 청소년 성장 도표를 이용하여, Z-score 로 변환하였다. 목둘레는 갑상설골막(thyrohyoid membrane) 부위에서 측정하였고, 허리둘레는 상전장골극(anterior-superior iliac spine)에서 측정하였다. 혈압은 디지털 혈압측정장치 (ProBP 3400, Welch Allyn, Skaneateles Falls, NY, USA)를 이용하여 2 번 측정하고, 그 평균치를 분석에 사용하였다. 체지 방 비율은 체지방 측정기를 이용하여 측정하였다(InBody J10, Biospace, Seoul, Korea). 편도선의 크기는 이비인후과 전문 의가 Friedman 등급척도를 이용하여 1 4단계로 분류하였 다. ${ }^{9}$ 측면경부 사진(lateral neck X-ray)을 촬영하여 아데노이 드 대 비인두 비율(ratio of adenoid size to nasopharynx aperture)을 구하였다. ${ }^{10)}$

\section{학부모 설문 및 지능검사}

설문지(Table 1)의 첫 부분에는 지난 4주 동안 학생의 코골 이 정도와 주간 졸림의 정도, 임신 기간, 출생 체중, 만성비염 유무, 아버지와 어머니의 코골이 정도와 아버지의 흡연 상태에 대한 질문이 포함되었다. 코골이에 대해서는 학생이 약간, 적 당히 혹은 자주 코를 고는 경우에 코골이 소아로 정의하였고, 전혀 혹은 거의 골지 않는 경우는 비코골이 소아로 정의하였 다. 비폐색, 콧물, 재채기, 눈 및 코 가려움 중 2 개 이상의 증상
이 3 개월 이상 지속될 경우 만성비염이 있다고 정의하였다. ${ }^{11)}$ 설문지의 두 번째 부분은 행동장애의 정도를 측정하기 위해 고안되었고, 주의력결핍/과잉행동장애 기준을 설문 내용으로 채택하였다. ${ }^{12)}$ 질문은 세 부분, 즉 부주의, 과잉행동, 그리고 충동성으로 나뉘어져 있고, 각각은 $9,6,3$ 개의 질문으로 이루 어져 있으며, 해당 항목 개수를 그 항목의 점수로 하였다. 인지 능력을 측정하기 위하여 Raven's progressive matrix를 사용 하였다. ${ }^{13)}$

\section{체혈검사}

공복 혈당, 당화 혈색소, 인슐린, 간 효소 수치(AST 및 ALT), 총 콜레스테롤, $\mathrm{LDL}$ 과 $\mathrm{HDL}$ 콜레스테롤, 중성 지방, 갑상선 자극 호르몬, T3, T4, 소마토메딘 C, C-반응성 단백질, 헤모글 로빈, 혈소판 수치들을 포함한 포괄적인 혈액 검사를 하였다.

본 연구는 건국대학교병원 임상시험심사위원회의 승인 (KUH1110015)을 받았으며, 임상연구정보서비스에 등록 (KCT0000699)되었다.

\section{통 계}

모든 측정 수치에 대해 코골이 소아와 비코골이 소아 간에 비교를 하였다. 편도선 크기, 주간 졸림 및 부모의 코골이 정 도를 비교하기 위해서는 Wilcoxon rank sum test를 사용하 였고, 만성비염 유병률과 아버지의 흡연 상태를 분석하기 위 하여 Pearson chi-squared test를 사용하였다. 다른 모든 측 정 수치는 정규분포를 확인한 후 Student t-test를 사용하여 비교하였다. $p$-value가 0.05 미만일 때 통계적 유의성이 있다 고 판단하였고, SPSS 통계 소프트웨어(IBM SPSS Statistics 20, IBM, Armonk, NY, USA)를 사용하였다.

\section{결 과}

1 학년 전체 208명의 학생 중, 175 명이 최종적으로 연구에 포 함되었다. 평균 연령은 7세(6.6 7.5세)였다. 175명의 참가자 중, 55 명(31.4\%)이 코골이 소아였고, 120 명은 비코골이 소아였다. 코골이는 남아에서 여아보다 더 흔했다 $(p=0.020)$. Table 2에 모든 연구결과를 요약하였다.

\section{신체검사}

체질량 지수 Z-score(0.49 \pm 1.18 vs. $-0.02 \pm 1.07, p=0.006)$, 목둘레(25.9 $\pm 1.8 \mathrm{~cm}$ vs. $25.2 \pm 1.8 \mathrm{~cm}, p=0.023)$ 와 허리둘레 $(56.3 \pm 8.1 \mathrm{~cm}$ vs. $53.4 \pm 6.8 \mathrm{~cm}, p=0.015)$ 모두 비코골이 소 아에 비해 코골이 소아에서 의미 있게 컸다. 만성비염 유병률 (28/55 vs. 27/117, $p<0.001)$ 도 코골이 소아에서 증가되어 있었 
Table 1. Parent's questionnaire

Part 1

1. 지난 4주 동안 자녀분이 얼마나 자주 큰 코골이가 있었습니까?
1) 전혀 없다
2) 거의 없다
3) 약간 있다
4) 적당히 있다
5) 자주 있다
6) 매우 자주 있다
7) 항상 있다

2. 지난 4주 동안 자녀분이 얼마나 자주 지나치게 나른하고 졸리웠습니까?
1) 전혀 없다
2) 거의 없다
3) 약간 있다
4) 적당히 있다
5) 자주 있다
6) 매우 자주 있다
7) 항상 있다

3. 자녀분의 출생 주수와 출산 시 몸무게는 얼마였나요?

4. 자녀분이 최근 3개월 이상 다음 증상이 있었나요?
1) 코가 막힌다
2) 맑은 콧물이 흐른다
3) 재채기를 자주 한다
4) 코가 가렵다
5) 눈이 가렵다

5. 아버지는 코를 고시나요?
1) 전혀 골지 않는다
2) 때때로 곤다
3) 항상 곤다

6. 어머니는 코를 고시나요?
1) 전혀 골지 않는다
2) 때때로 곤다
3) 항상 곤다

7. 아버지가 담배를 피우시나요?
1) 피운다
2) 피우지 않는다
3) 과거에 피웠으나 현재 끊었다

Part 2

아래 항목들 중에서 학부모님이 판단하시기에 최근 6개월간 자녀분의 행동과 일치하는 항목에 $\bigcirc$ 표 해 주시기 바랍니다 1. 부주의에 관해서

1) 세부적인 면에 대해 면밀한 주의를 기울이지 못하거나, 학업, 작업, 또는 다른 활동에서 부주의한 실수를 저지른다

2) 일을 하거나 놀이를 할 때 지속적으로 주의를 집중할 수 없다

3) 다른 사람이 말을 할 때 경청하지 않는 것으로 보인다

4) 지시를 완수하지 못하고, 학업, 잡일 등에서 임무를 수행하지 못한다

5) 과업과 활동을 체계화하지 못한다

6) 학업 또는 숙제 같은 데 참여하기를 피하고 싫어하고 반항한다

7) 활동하거나 숙제하는 데 필요한 물건들(예: 장난감, 학습과제, 연필, 책, 또는 도구)을 잃어버린다

8) 외부의 자극에 의해 쉽게 산만해진다

9) 일상적인 활동을 잊어버린다

2. 과잉행동에 관해서

1) 손발을 가만히 두지 못하거나 의자에 앉아서도 몸을 움직인다

2) 앉아 있도록 요구되는 교실이나 다른 상황에서 자리를 떠난다

3) 부적절한 상황에서 지나치게 뛰어다니거나 기어오른다

4) 조용히 여가 활동에 참여하거나 놀지 못한다

5) "끊임없이 활동하거나" 마치 "무엇인가에 쫓기는 것"처럼 행동한다

6) 지나치게 수다스럽게 말을 한다

3. 충동성에 관해서

1) 질문이 채 끝나기 전에 성급하게 대답한다

2) 차례를 기다리지 못한다

3) 다른 사람의 활동을 방해하고 간섭한다(예: 대화나 게임에 참견한다)

다. 그러나 키, 편도선 및 아데노이드 크기, 체지방 비율, 수축 기 및 이완기 혈압은 코골이 소아와 비코골이 소아 사이에 통 계학적으로 유의한 차이가 없었다.

\section{출산 및 가족력 관계}

코골이 소아의 어머니는 비코골이 소아 어머니보다 코를 더 자주 골았다 $(p=0.020)$. 그러나, 임신 기간, 출생 체중, 아버지 의 코골이 정도, 흡연 비율 등은 두 군 간에 차이가 없었다.

\section{행동장애 및 인지능력}

부주의와 충동성에 대한 설문 점수는 비코골이 소아보다 코골이 소아에서 의미 있게 높았다. 그러나, 과잉행동, 주간 졸 림의 정도 및 지능검사 수치는 두 군 간에 차이가 없었다.

\section{혈액검사}

혈액검사 결과에서는 코골이 소아와 비코골이 소아 사이에 통계학적으로 유의한 차이를 발견할 수 없었다. 
Table 2. Comparison between snoring and non-snoring children

\begin{tabular}{|c|c|c|c|}
\hline & 코골이(55명) & 비코골이(120명) & $p$-value \\
\hline 남아/여아 & $40 / 15$ & $65 / 55$ & $0.020^{*}$ \\
\hline \multicolumn{4}{|l|}{ 신체적 특징 } \\
\hline 키 Z-score & $0.26 \pm 1.12$ & $0.09 \pm 0.95$ & 0.305 \\
\hline 체지량지수 Z-score & $0.49 \pm 1.18$ & $-0.02 \pm 1.07$ & $0.006^{*}$ \\
\hline 목둘레(cm) & $25.9 \pm 1.8$ & $25.2 \pm 1.8$ & $0.023^{*}$ \\
\hline 허리둘레(cm) & $56.3 \pm 8.1$ & $53.4 \pm 6.8$ & $0.015^{*}$ \\
\hline 체지방 비율(\%) & $22.1 \pm 8.3$ & $20.3 \pm 6.9$ & 0.128 \\
\hline 수축기 혈압(mm Hg) & $100.2 \pm 12.3$ & $99.9 \pm 9.1$ & 0.852 \\
\hline 확장기 혈압(mm Hg) & $59.1 \pm 9.3$ & $57.4 \pm 6.8$ & 0.166 \\
\hline 편도크기(1/2/3/4) & $17 / 8 / 19 / 8$ & $53 / 22 / 27 / 14$ & 0.450 \\
\hline 아데노이드 대 비인두 비율 & $60.5 \pm 14.4$ & $57.8 \pm 11.8$ & 0.190 \\
\hline 만성비염 유병률 & $28 / 55$ & $27 / 117$ & $<0.001^{*}$ \\
\hline \multicolumn{4}{|l|}{ 출산 및 가족관련 특징 } \\
\hline 임신 기간(주) & $39.1 \pm 1.5$ & $38.9 \pm 1.6$ & 0.470 \\
\hline 출생 몸무게 (kg) & $3.38 \pm 0.41$ & $3.28 \pm 0.37$ & 0.112 \\
\hline 아버지 코골이(없음/때때로/항상) & $4 / 28 / 22$ & $11 / 77 / 28$ & 0.087 \\
\hline 어머니 코골이(없음/때때로/항상) & $14 / 38 / 2$ & $54 / 60 / 1$ & $0.020^{*}$ \\
\hline 아버지 흡연(흡연/비흡연/과거흡연) & $36 / 13 / 6$ & $60 / 33 / 23$ & 0.190 \\
\hline \multicolumn{4}{|l|}{ 행동장애 및 지능 } \\
\hline 부주의 & $2.44 \pm 2.33$ & $1.50 \pm 2.0$ & $0.007^{*}$ \\
\hline 과잉행동 & $1.00 \pm 1.35$ & $0.74 \pm 1.25$ & 0.218 \\
\hline 충동성 & $0.85 \pm 1.07$ & $0.46 \pm 0.80$ & $0.010^{*}$ \\
\hline 주간 졸림 & $1.98 \pm 0.85$ & $1.87 \pm 0.91$ & 0.428 \\
\hline 지능검사 & $55.6 \pm 34.0$ & $57.5 \pm 33.4$ & 0.875 \\
\hline \multicolumn{4}{|l|}{ 혈액검사 } \\
\hline $\mathrm{FBS}(\mathrm{mg} / \mathrm{dL})$ & $87.1 \pm 6.9$ & $86.9 \pm 8.3$ & 0.893 \\
\hline $\mathrm{HbAlc}(\%)$ & $5.43 \pm 0.19$ & $5.42 \pm 0.23$ & 0.785 \\
\hline Insulin (IU/mL) & $4.76 \pm 3.07$ & $4.45 \pm 3.03$ & 0.556 \\
\hline AST (IU/L) & $27.1 \pm 4.7$ & $28.3 \pm 6.0$ & 0.225 \\
\hline ALT (IU/L) & $11.3 \pm 5.4$ & $11.4 \pm 5.9$ & 0.867 \\
\hline Cholesterol (mg/dL) & $166.1 \pm 21.8$ & $167.8 \pm 26.1$ & 0.690 \\
\hline Triglyceride (mg/dL) & $61.3 \pm 35.5$ & $59.8 \pm 28.9$ & 0.770 \\
\hline HDL-cholesterol (mg/dL) & $58.3 \pm 12.6$ & $57.0 \pm 9.7$ & 0.489 \\
\hline $\mathrm{TSH}(\mathrm{IU} / \mathrm{mL})$ & $3.17 \pm 1.86$ & $3.35 \pm 1.46$ & 0.496 \\
\hline $\mathrm{T} 3$ (ng/dL) & $181.3 \pm 23.3$ & $184.3 \pm 24.7$ & 0.463 \\
\hline T4 (ng/dL) & $1.40 \pm 0.18$ & $1.40 \pm 0.16$ & 0.650 \\
\hline Somatomedin C (ng/mL) & $231.1 \pm 80.4$ & $220.3 \pm 64.3$ & 0.359 \\
\hline $\mathrm{CRP}(\mathrm{mg} / \mathrm{dL})$ & $0.102 \pm 0.175$ & $0.144 \pm 0.348$ & 0.411 \\
\hline Hemoglobin (g/dL) & $12.9 \pm 0.6$ & $12.9 \pm 0.6$ & 0.515 \\
\hline Platelet $\left(10^{3} / \mathrm{dL}\right)$ & $337.9 \pm 69.9$ & $331.6 \pm 63.5$ & 0.577 \\
\hline
\end{tabular}

*means $p$-value $<0.05$

\section{고 찰}

소아 코골이의 유병률은 연구마다 상당한 차이를 보이는데 적게는 5\%에서 많게는 약 $30 \%$ 까지 보고하였다. ${ }^{1)}$ 하지만, 소 아 폐쇄성수면무호흡증후군의 유병률은 단지 $2 \%$ 정도이다. ${ }^{1)}$ 따라서, 소아 코골이의 대부분은 단순 코골이라고 추정된다. 그럼에도 불구하고 지금까지 대부분의 연구는 폐쇄성수면무
호흡증후군에 대해 이루어졌고, 코골이에 대한 연구는 상대적 으로 적은 관심을 받았으나, 무호흡 혹은 저호흡이 동반되지 않은 단순 코골이도 여러 문제를 유발할 수 있다는 보고들이 발표되면서, 코골이도 점차 주목을 받게 되었다. ${ }^{1)}$

소아 코골이나 폐쇄성수면무호흡증후군의 발생과 관련해서 성별, 체질량 지수, 편도선 및 아데노이드의 크기, 알레르기비 염 유무, 미숙아, 부모의 코골이 또는 흡연상태 등이 영향을 미 
친다는 연구들이 있으나., ${ }^{14,15)}$ 반대되는 연구들도 있어 여전히 논란 중이다. ${ }^{4,5,16)}$

성인에서는 남성에서 코골이나 폐쇄성수면무호흡증후군의 발병비율이 현저히 높으나 소아에서는 남녀가 비슷하다는 연 구가 많다..$^{16-18)}$ 이러한 결과에 대해 다수의 연구자들은 성인 에서는 비만이 주원인인 반면, 소아에서는 편도 및 아데노이 드 비대가 주원인이기 때문이라고 설명하였다. ${ }^{16-18)}$ 하지만, 본 연구에서는 남아의 코골이 빈도가 여아에 비해 의미 있게 높 았으며, 편도 및 아데노이드 크기가 코골이 소아와 비코골이 소 아 간에 차이가 없었다. 또한, 코골이 소아에서 체질량지수 및 목둘레, 허리둘레가 비코골이 소아에 비해 증가해 있었다. 따 라서, 최근 국내의 소아 코골이는 성인과 마찬가지로 비만과 연관되어 있고, 남아에서 더 많은 이유는 남아에서 비만의 비 율이 여아보다 높기 때문이라고 추정된다. 편도 및 아데노이 드 크기가 코골이 소아와 비코골이 소아 간에 차이가 없었던 결과에 대해서는 여러 해석이 가능하겠다. 다수의 연구들에서 코골이 환아들이 편도 및 아데노이드가 큰 경우가 많고, 편도 아데노이드 제거술 후 대부분 증상의 호전을 보이는 등 소아 코골이가 편도 및 아데노이드 비대와 밀접히 관련되어 있다 고 주장해, ${ }^{1,25)}$ 본 연구의 결과와 상충되기 때문이다. 다만 지 금까지 편도 및 아데노이드 수술 결과에 대한 연구는 대부분 병원을 찾은 환아들을 대상으로 시행되었고, 본 연구는 일반 학생들을 대상으로 시행한 코호트 연구이므로 결과에 다소 간의 차이가 있을 것으로 추정한다. 또한, 편도와 아데노이드 크기 측정에 사용한 Friedman stage나 측면경부 사진의 도구 적 부정확함이 실제 차이를 반영하지 못했을 가능성도 고려해 야 하겠다.

일부 연구에서 폐쇄성수면무호흡증후군 환아들은 수면 중 분비되는 성장 호르몬의 부족으로 인해 성장지연이 초래될 수 있다고 보고하였으나, ${ }^{19,20)}$ 본 연구에서는 코골이 소아와 비 코골이 소아 간에 키 또는 소마토메딘 C 혈중량에 차이가 없 었다. 소마토메딘 $\mathrm{C}$ 는 성장호르몬이 효과를 나타내는 주요 매개물질로, 성장호르몬의 효과를 간접적으로 반영하며 결 핍될 경우 키가 작아질 수 있다. ${ }^{20)}$ 본 연구 결과를 보면 소아 코골이가 성장에 미치는 영향은 다소 제한적이라고 추정할 수 있으나, 본 연구가 아직은 단면연구에 불과해 추후 경과를 지 켜보아야 할 것 같다.

또한 코골이나 폐쇄성수면무호흡증후군이 교감신경계를 자극하여 고혈압을 일으킬 수 있는 것으로 알려져 있었지만, 이번 연구에서는 코골이 소아와 비코골이 소아 간에 혈압의 차 이는 없었다. ${ }^{6}$

알레르기비염이 소아 코골이 및 폐쇄성수면무호흡증후군 을 악화시킨다는 보고가 많은데, 이는 알레르기비염으로 인해
상기도 폐쇄가 더욱 심해진 것이 하나의 원인이 될 수 있고, 알 레르기비염으로 인한 수면방해가 코골이 및 폐쇄성수면무호 흡증후군을 더 악화시킨다는 연구도 있다. ${ }^{21)}$ 본 연구에서도 만성비염의 유병률이 코골이 소아에서 비코골이 소아에 비해 월등히 높아, 비염이 코골이를 악화시킨다고 하는 기존 연구와 일치되는 결과를 얻었다.

출산 및 가족력 관계에 대한 연구에서 조산아의 경우 폐쇄 성수면무호흡증후군의 발생이 증가한다는 보고가 있고, 부 모가 코골이나 폐쇄성수면무호흡증후군이 있는 경우 자녀의 발생률도 증가한다는 보고도 있었다. ${ }^{4,10)}$ 본 연구에서는 출생 주수나 출생시 몸무게가 코골이와 비코골이 소아 사이에 차 이는 없었고, 아버지의 코골이나 흡연과의 관련성도 없었다. 다 만 코골이 아동의 어머니들에서 비코골이 아동의 어머니에 비 해 코를 고는 비율이 높았다. 이는 어머니의 식생활 습관이 자 녀들에게 전해지는 과정에서 함께 비만해져 코를 곤다고 추정 해 볼 수도 있겠다.

소아 코골이 및 폐쇄성수면무호흡증후군 환아들이 과잉행 동이나 인지장애를 경험하는 비율이 높은 것으로 보고되었 는데, ${ }^{22-25}$ 본 연구에서도 부주의와 충동성 점수가 코골이 소 아에서 증가되어 있었다. 이는 수면부족과 대뇌의 저산소 손 상으로 인해 발생한다는 연구들이 있다. ${ }^{20-22)}$ 하지만 과잉행 동, 주간 졸림에 있어서는 차이가 없었다.

각종 혈액검사에서는 코골이 소아와 비코골이 소아 사이의 차이점이 없었다. 다른 연구들에서는 폐쇄성수면무호흡증후 군이 대사증후군, 적혈구 증가, 갑상선 질환 또는 $\mathrm{C}$-반응성 단백질 증가와 관련이 있다는 보고들이 있었다. ${ }^{17,26-28)}$

본 연구의 가장 큰 한계점은 제한된 자원으로 인해 수면다 원검사를 시행하지 못한 점이다. 따라서 단순 코골이 환아와 폐쇄성수면무호흡증후군 환아를 구별하지 못했고, 특히 폐쇄 성수면무호흡증후군 환아에서 무호흡-저호흡 지수에 의한 분류도 시행하지 못하였다. 다만 대부분의 연구에서 폐쇄성 수면무호흡증후군 환아의 유병률이 낮은 것으로 보고하였으 므로, ${ }^{1)}$ 본 연구의 코골이 소아들도 대부분은 단순 코골이라 고 추정하였다. 또한 코골이와 비코골이를 정의함에 있어 다 소 임의적인 면이 있었다. 하지만, 코골이에 대한 명확한 정의 는 없고, 대부분의 논문에서 각자 정의한 기준을 사용해 연구 하였다. 따라서 본 연구의 결과들을 해석함에 있어 이러한 제 한점들을 고려하여야 할 것이다.

\section{Acknowledgments}

This research was supported by Basic Science Research Program through the National Research Foundation of Korea (NRF) funded by the Ministry of Education, Science and Technology (2011-0022916). 


\section{REFERENCES}

1) Tauman R, Gozal D. Obstructive sleep apnea syndrome in children. Expert Rev Respir Med 2011;5(3):425-40.

2) Marcus CL, Brooks LJ, Draper KA, Gozal D, Halbower AC, Jones J, et al. Diagnosis and management of childhood obstructive sleep apnea syndrome. Pediatrics 2012;130(3):e714-55.

3) Owen GO, Canter RJ, Robinson A. Snoring, apnoea and ENT symptoms in the paediatric community. Clin Otolaryngol Allied Sci 1996;21(2): $130-4$.

4) Aurora RN, Zak RS, Karippot A, Lamm CI, Morgenthaler TI, Auerbach $\mathrm{SH}$, et al. Practice parameters for the respiratory indications for polysomnography in children. Sleep 2011;34(3):379-88.

5) Roland PS, Rosenfeld RM, Brooks LJ, Friedman NR, Jones J, Kim $\mathrm{TW}$, et al. Clinical practice guideline: polysomnography for sleepdisordered breathing prior to tonsillectomy in children. Otolaryngol Head Neck Surg 2011;145(1 Suppl):S1-15.

6) Rauscher H, Popp W, Zwick H. Systemic hypertension in snorers with and without sleep apnea. Chest 1992;102(2):367-71.

7) Jennum P, Sjøl A. Snoring, sleep apnoea and cardiovascular risk factors: the MONICA II Study. Int J Epidemiol 1993;22(3):439-44.

8) Zieliński J, Zgierska A, Polakowska M, Finn L, Kurjata P, Kupść W, et al. Snoring and excessive daytime somnolence among Polish middle-aged adults. Eur Respir J 1999;14(4):946-50.

9) Friedman M, Wilson MN, Pulver T, Pandya H, Joseph NJ, Lin HC, et al. Screening for obstructive sleep apnea/hypopnea syndrome: subjective and objective factors. Otolaryngol Head Neck Surg 2010; 142(4):531-5.

10) Fujioka M, Young LW, Girdany BR. Radiographic evaluation of adenoidal size in children: adenoidal-nasopharyngeal ratio. AJR Am J Roentgenol 1979;133(3):401-4.

11) Wallace DV, Dykewicz MS, Bernstein DI, Blessing-Moore J, Cox L, Khan DA, et al. The diagnosis and management of rhinitis: an updated practice parameter. J Allergy Clin Immunol 2008;122(2 Suppl):S1-84

12) American Psychiatric Association. Diagnostic and statistical manual of mental disorders, text revision (DSM-IV-TR). 4th ed. Washington, DC: American Psychiatric Publishing, Inc;2000. p.85-102.

13) Raven J. The Raven's progressive matrices: change and stability over culture and time. Cogn Psychol 2000;41(1):1-48.

14) Chae SW, Choi G, Hwang KS, Lee DJ, Choi CS, Hwang SJ. The incidence and clinical symptoms of palatine tonsillar hypertrophy in elementary school children. Korean J Otolaryngol-Head Neck Surg 2000;43(12):1342-5.

15) Park JJ, Shim HJ, Choi SM, Yoon SW, Shin HB, Kim EJ. Effect of adenotonsillectomy on pediatric obstructive sleep apnea. Korean J Otorhinolaryngol-Head Neck Surg 2007;50(8):667-71.

16) Karpinski AC, Scullin MH, Montgomery-Downs HE. Risk for sleepdisordered breathing and executive function in preschoolers. Sleep Med 2008;9(4):418-24.

17) Tauman R, Gozal D. Obesity and obstructive sleep apnea in children. Paediatr Respir Rev 2006;7(4):247-59.

18) Jeyakumar A, Fettman N, Armbrecht ES, Mitchell R. A systematic review of adenotonsillectomy as a risk factor for childhood obesity. Otolaryngol Head Neck Surg 2011;144(2):154-8.

19) Bonuck K, Parikh S, Bassila M. Growth failure and sleep disordered breathing: a review of the literature. Int J Pediatr Otorhinolaryngol 2006;70(5):769-78.

20) Kiris M, Muderris T, Celebi S, Cankaya H, Bercin S. Changes in serum IGF-1 and IGFBP-3 levels and growth in children following adenoidectomy, tonsillectomy or adenotonsillectomy. Int J Pediatr Otorhinolaryngol 2010;74(5):528-31.

21) Lin SY, Melvin TA, Boss EF, Ishman SL. The association between allergic rhinitis and sleep-disordered breathing in children: a systematic review. Int Forum Allergy Rhinol 2013;3(6):504-9.

22) O'Brien LM, Mervis CB, Holbrook CR, Bruner JL, Klaus CJ, Rutherford $\mathrm{J}$, et al. Neurobehavioral implications of habitual snoring in children. Pediatrics 2004;114(1):44-9.

23) Kim JK, Lee JH, Lee SH, Hong SC, Cho JH. School performance and behavior of Korean elementary school students with sleep-disordered breathing. Ann Otol Rhinol Laryngol 2011;120(4):268-72.

24) Kim JK, Lee JH, Lee SH, Hong SC, Cho JH. Effects of sleep-disordered breathing on physical traits, school performance, and behavior of Korean elementary school students in the upper grade levels. Ann Otol Rhinol Laryngol 2012;121(5):348-54.

25) Choi JH, Lee SH, Lee HM, Lee JK, Kwon SY, Shin C, et al. Correlation between quality of life and personality, behavior problem in children with sleep disordered breathing. Korean J Otolaryngol-Head Neck Surg 2005;48(10):1235-41.

26) Gozal D, Crabtree VM, Sans Capdevila O, Witcher LA, KheirandishGozal L. C-reactive protein, obstructive sleep apnea, and cognitive dysfunction in school-aged children. Am J Respir Crit Care Med 2007; 176(2):188-93

27) Choi JB, Loredo JS, Norman D, Mills PJ, Ancoli-Israel S, Ziegler MG, et al. Does obstructive sleep apnea increase hematocrit? Sleep Breath 2006;10(3):155-60.

28) Kittle WM, Chaudhary BA. Sleep apnea and hypothyroidism. South Med J 1988;81(11):1421-5. 